Przegląd Badań Edukacyjnych Educational Studies Review

ISSN 1895-4308

nr 35 (2/2021), s. 153-173

ORYGINALNE ARTYKUtY BADAWCZE

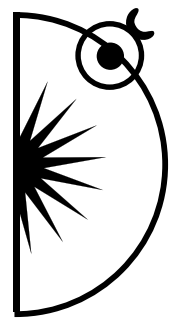

Anna Dudak

Maria Curie-Sklodowska University in Lublin, Poland

e-mail: anna.dudak@mail.umcs.pl

ORCID: https://orcid.org/0000-0002-7491-2980

\title{
Men's Experiences in Feminized Occupations on the Example of Selected Professions
}

http://dx.doi.org/10.12775/PBE.2021.036

\begin{abstract}
:
The issues raised in this article concern the functioning of men in feminized professions. The aim of the study was to gather experiences of men working in jobs dominated by women. The research included twenty men and was conducted between February and April 2020 in Poland, using a narrative interview. Research problems were focused on men's attitudes toward their jobs, the assessment of career advancement opportunities, advantages and disadvantages resulting from working in a feminine environment, relations with colleagues and employers, and reactions of their environment. The interviews revealed a relatively positive image of men's experiences relating to working with women. The respondents did not notice any specific difficulties in their professions caused by gender stereotypes. They expressed a view that working among women was like any other job. Few difficulties mentioned by the respondents were related mostly to the issue of assistance in activities requiring strength or technical knowledge rather than competences related to a specific profession. Moreover, the interviewees treated their professions as an opportunity for self-development and for gaining experience that they would not have been able to gain in a typically male environment.
\end{abstract}

Keywords: men, profession, feminization, gender stereotypes. 


\section{Issues in feminized professions - introduction}

Gender is an important element in the division of the labour market. It is visible in its vertical and horizontal segregation and leads to unequal treatment of men and women in terms of employment conditions and occupational prestige. The changes taking place in social roles, including professional roles, lead to an increasing research interest in the functioning of individuals in feminized and masculinized occupations. Such professions are characterized by the dominance of one gender, which has a great impact on their attractiveness.

The issues of men taking up feminized professions are usually discussed in relation to the following occupations: teachers (Fuszara, 2008; Gromkowska-Melosik, 2013; Walczak, 2016); social workers (Pokrzywa, 2016; 2017), librarians (Klimczak-Ziółek, 2005; Marcinkowski, 2005; Kamińska-Berezowska \& Suchacka, 2015; Folga, 2016; Ziarkowski, 2019), or nurses (Kapała \& Rucki, 2008; Simpson, 2009; Kluczyńska, 2012; 2017; Domagała et al., 2013). Research on functioning of males in typically female-dominated vocations and professions is studied under a wider framework of research on gender inequality in work, promotion opportunities, discrimination or bias (Blau \& Kahn, 2000; Huffman, 2004; Blau et al., 2006; Kuropatwa, 2014).

In relation to these theories, one can mention the concept of occupational segregation, in which discrimination in the labour market results from the fact that females and males tend to work in distinct occupations (Kuropatwa, 2014). This theory explains the propensity to choose occupations according to genderspecific roles, which leads to a belief that there are typically female and typically male occupations (Lipińska-Grobelny, 2012). Traditional economic explorations of gender pay gap and occupational segregation have focused on factors that can be described as gender-specific, i.e. differences in qualifications or how people with similar qualifications are treated by the labour market (Blau \& Kahn, 2000, p. 82).

The phenomenon of discrimination and inequality at work is also discussed under monopsonist theory, which assumes that female labour supply is less flexible than male labour supply (Kuropatwa, 2014). Moreover, as M. Huffman (2004, p. 326) argues, increased inequality, especially in better-paid jobs, is generally consistent with the "glass ceiling" effect, which blocks women from advancing up the organizational hierarchy. A concept worthy of a mention in this context is gender desegregation, which occurs when more and more women perform occupations previously defined as typically male, resulting in a loss of prestige and a drop in pay levels (Reskin \& Ross, 1990, after: Domański, 1999, p. 36.). In this context, it is worth examining the impact of the increase in male employment in these occupations on the attractiveness of female-dominated professions. 
The division into feminized and masculinized occupations results primarily from socio-cultural patterns, which stereotypically determine the type of job undertaken by an individual. The division is also strongly conditioned by economic factors. The continuing division into typically male and typically female professions is related to the stereotype that women are more likely to work in jobs that require lower qualifications, have no promotion opportunities, and are less paid. Moreover, they supposedly look for jobs in less prestigious professions, which do not require excessive availability and additional training (Janicka, 1995, pp. 89-91). On the other hand, men are more likely to take well-paid jobs that give prestige and recognition as well as promotion opportunities (England, 2010; Moore, 2018). According to J. Klimczak-Ziółek (2005, p. 105), quantitative disproportion in the representation of people of a specific gender as well as the qualitative difference in access to valuable resources, such as prestige, salary, advancement opportunities and the nature of work, are characteristic for the division into feminized and masculinized professions. An interesting claim regarding the attractiveness of the feminized teaching profession was put forward by A. Gromkowska-Melosik (2013, p. 86). She pointed out that feminization is a consequence rather than a cause of the profession losing its attractiveness. According to this author, the increasing number of women in a given profession is either a testimony to its historically low status or to a decrease of prestige due to social and economic reasons.

Social change (related primarily to the individuals taking up professional roles and tasks in accordance with their own interests), drive towards self-realization, and to a large extent also the possibility of finding a job are among main factors behind a progressive decrease in the number of feminized professions (Fuszara, 2008; McDonald, 2013). Gender and a stereotypical assessment of predispositions for a specific job do not create a significant barrier preventing one from achieving their goals. To a large extent, this phenomenon counteracts social exclusion, which affects people who want to become professionally active because of their developmental needs (Nowak, 2018, p. 86). As pointed out by F.D. Blau and L.M. Kahn (2000, p. 78), an increase in the gender parity in occupational groups and better vocational training of both sexes may be the reasons for a decrease in pay discrimination.

Men taking up professional activity in occupations dominated by women are usually motivated by a current tendency to abandon the traditional model of masculinity (Cross \& Bagilhole, 2002; Shen-Miller \& Smiler, 2015), previous experiences, gained for instance during student internships (Fuszara, 2008), family professional traditions, or by personal interests connected with willingness to work with people in need of support and help (Whitaker, 2008; Dudak, 2020). Yet, this choice can also be a result of a coincidence (Dudak, 2020). 
Research conducted (Cross \& Bagilhole, 2002; Klimczak-Ziółek, 2005; Fuszara, 2008; Kluczyńska, 2009; Kaźmierczak, 2013; Shen-Miller \& Smiler, 2015; Dudak, 2019, 2020) on the functioning of men in feminized professions shows that men very often are confronted with the stereotypical perception of the motives for choosing such a profession. A desire for a quick promotion, which is allegedly more probable with men precisely because of working in a feminized environment, is a common preconception.

\section{Research purpose and method}

The research aimed to identify experiences of men working in professions dominated by women. It was carried out in the qualitative orientation, framed within the biographical perspective. The major objective was to learn about and analyze men's professional situation as a leading biographical experience (Bauman, 1995; Ostrouch, 2004, p. 90). Narrative interview was the research method employed. Additionally, it was assumed that, in line with the concept of F. Schütze, individuals shape their behaviour in the course of an interaction with the environment, and that the activity undertaken by men in feminized professions is subject to conscious construction. Moreover, it was assumed that there was a fundamental agreement between the men's narratives and their real-life experiences (Urbaniak-Zając \& Kos, 2013, pp. 91-92). In the research concerning this particular group, the outcomes of the application of the method of narrative interview may constitute a support and inspiration for programmatic social change. This might be the case because narratives of men working in an environment dominated by women may bring more attention to the obstacles that men have to deal with while facing gender discrimination. They can also show that there is professional space for men in which they can cope equally well as women (Denzin \& Lincoln, 2009, p. 4).

The interviews provided an opportunity to answer the following research questions:

1. How do men evaluate their work in a feminized environment?

2. What advantages and disadvantages do men notice when working among women?

3. What reactions do men get from their family and friends in relation to their professional functioning?

The presented analysis is part of a wider research on the functioning of men in feminized professions. All interviews were conducted in direct contact with participants and were recorded. Then, the entire collected material was 
transcribed and organized in accordance with the guidelines established at the stage of research design. First, formal analysis was performed. Text was divided according to the content components (Urbaniak-Zając \& Kłos, 2013, p. 104), which were then thoroughly analyzed. This step allowed learning about the men's experiences, opinions, and feelings concerning working in an environment dominated by women.

\section{Characteristics of the study group}

The study employed purposive sampling. The participants were twenty men with experience of working in professions dominated by women. Selecting feminized professions was based on the characteristics of the occupations (Kobiety i mężczyźni na rynku pracy [Men and Women on Labour Market], 2018). The study group included seven social workers, seven librarians, four teachers and two office staff members working with educational institutions. The research was conducted between February and April 2020 in Poland.

The men participating in the interviews were aged between 26 and 64 . The average age for the entire group was 42 years. As a result of different age, interviewees' working experience in a given profession varied. The shortest working experience period was one year, the longest - 44 years. The average was 19 years. Most of the interviewees had higher education and held a master's degree (16 men), three men had secondary education and one had higher vocational education. The majority of the participants were married ( $12 \mathrm{men}$ ), four of the respondents were in an informal relationship and four were single. Most often, they had one or two children; six of the interviewees had no children.

\section{Men among women - experiences of working in a feminized environment}

The undertaken research sought knowledge about men's experiences and evaluation of work in female-dominated environments. The analysis of the interviews allowed to identify three approaches in terms of assessment.

The first group indicated in their narratives that men encounter difficulties at work in feminized surroundings. These are examples of such statements ${ }^{1}$ :

${ }^{1}$ All statements of the interviewees quoted in this article are a translation of the original Polish language narratives. 
I_16: It is definitely harder for men. Women use gender differences very often. They say such things as 'you are the guy here, do it', 'this should be your job'. If there is a difficult client, the director (a woman) refers the matter to me.

I_20: It is harder for men to get promoted. I can say that they are discriminated and used by women. As a man, I am assigned to work in more challenging environments, with more problematic individuals and families. My female co-workers with shorter working experience received regular pay bonuses. Their job titles were changed to '...coordinator' and thus the additional compensation was granted.

It is worth emphasizing that among the participants, men who experienced difficulties related to working in a female-dominated environment were a definite minority.

The second group were respondents who emphasized the advantages of working in an environment dominated by women, mainly due to the fact that, being in the minority, they were often getting special treatment (Fuszara, 2008):

I_15: In my opinion, men working among women have it much easier. Sometimes all you need to do is smile or say something nice and it turns out that anything can be arranged.

I_19: I think it's easier. I do not notice any major difficulties. It is certainly more difficult when you want to talk to a man; meanwhile, you are surrounded by only women.

I_20: Men who teach and work among women have it easier. In such an environment, communication and cooperation is better.

I_9: It's easy for me, but it all depends on the team you are working with. I believe that if a man does not have problems in interactions with women, it will be easier for him to work in a feminized environment.

I_5: I think it is easier for us to be in a larger group of women. My colleagues are very helpful.

I_3: From my experience, it is easier for a man to work among women. Female colleagues often help with various professional issues. They are more understanding and willing to help. 
The narratives mentioned above revealed a positive image of women, pointing mainly to such features as being understanding and willing to help.

The third group, which was the largest one, consisted of men who emphasized that gender is not a factor determining the quality and nature of relationships in the work environment. The interviewees indicated no differences in professional qualifications:

I_14: I don't think it matters anymore, because nowadays men and women have similar qualifications.

They also emphasized the importance of good communication and professional approach to the job:

I_1: I don't have any negative opinions or memories. I was lucky. My female colleagues were and are very friendly, and I was able to communicate with them. We often collaborate on various projects. I think that if we avoid dividing people in the workplace (we are being professional men and women), there is hardly any room for problems. If any occur, they are a result of people's character, not the relations they are in because of the tasks they perform.

I_18: I believe that it doesn't depend on the number of women, but on the willingness to get along at work, types of personality and clarity regarding the responsibilities.

The participants emphasized that what matters most is the person's character and personality:

I_11: It's difficult to describe it. I think that the issues related to the work comfort depend more on character rather than gender. It should be noted that the opposite sex and its personal characteristics condition our behaviour and this also affects our work performance.

I_8: It depends on the people with whom you have been studying or working. Both women and men can be difficult. I admit that I prefer to work in a mixed group.

I_13: Both. Openness, kindness and communicativeness play an important role. It can be a hermetic environment in which it is difficult for a man to stand out or to have a say. This has never happened to me though. 
Having analysed these narratives, one could clearly see that gender is not regarded as an important factor in determining the quality of work experiences. The men revealed that what matters is the type and nature of work, responsibilities, and personal preferences. The following statements exemplify these assessments:

I_7: I guess it depends on individual preferences regarding work. A type of job and a work environment are also important factors. The work of a librarian is certainly not as stressful as the work of a teacher or nurse, although these are also highly feminized professions. A Most of the difficult experiences come from the environment and atmosphere, which is created by the conditions and nature of work. Overall, I don't think it makes jobs harder or easier.

I_6: There are certain barriers between men and women, resulting from behaviours, interests, or manners, which are difficult to eliminate. Based on my experience, I can't really tell what the degree of difficulty is.

I_12: In my opinion, it does not have an impact on the difficulty level. I think it is the same as if I worked in an environment where the parity of men and women is equal.

Research results seem intriguing, especially as regards the number of statements in which the respondents did not recognize as significant gender stereotypes, discrimination, or favoritism at work, even though these phenomena are very often indicated in the context of gender and its impact on relations at workplace (Cross \& Bagilhole, 2002; Shen-Miller \& Smiler, 2015; Dudak, 2019). The interviewees emphasized that they did not experience difficulties related to gender stereotypes, which are responsible for discriminating between male and female professions, impact the professional position and determine chances for professional success. The registered statements may suggest that the participants have a quite conscious approach to fulfilling professional tasks, which is based on maintaining good relations with the opposite sex. In their subjective assessment of experiences in a feminized work environment, men revealed that the difficulties faced when working with women did not result from the dominance of one gender, but were related to general working conditions and the personality traits of the colleagues. In this context, it can be interesting to learn what women working with men in both female- and male-dominated environments think about these issues. 
It is also worth noting that the vast majority of the respondents were satisfied with their jobs. The interviewees appreciated advantages and emphasized that more men should take up work in these professions. The following statement can serve as an example of such an opinion:

I_19: My experiences are definitely positive. However, I think that more men should pursue a career in this profession. After all, men think and act differently in some situations. I think that diversity would be helpful in occupations dominated by women.

However, in this statement, one can notice a belief that there are differences between men and women in terms of their approach to professional duties. Nevertheless, this claim is not of an evaluative nature.

One of the participants expressed his positive opinion by pointing out the opportunity for mutual support and help. It was phrased as follows:

I_3: I think I have great relationships. We support and help each other in difficult moments in our job.

The research results allow for the conclusion that the position presented by my interviewees with regard to their work experience in a female-dominated environment is in line with the modern paradigm of masculinity. The majority of the collected responses show that the division of professions according to gender is blurring. The stereotypical assessment of work quality by men taking up work in accordance with gender segregation is not an obstacle in the respondents' pursuit of their professional goals.

\section{Advantages and disadvantages of working in feminized professions}

The interviews revealed that the men see numerous advantages of working in a female-dominated environment. They mainly concern support and help from female co-workers:

I_15: I find women more accurate and helpful.

I_19: As a man, I am in the minority; and this is on the plus side. There are many female colleagues you can count on. You are able see how the opposite sex reacts 
to certain matters, which gives you an opportunity to compare different patterns. There's a lot you can learn from that.

The participants repeatedly mentioned advantages of working with women. They referred to women's traits and disposition as well as their approach to work.

I_14: In a mixed environment, I can observe better manners on both sides; that is softer language, kindness. This applies to both men and women.

In the assessments regarding the positive aspects of working with women, a recurrent theme was the possibility of gaining knowledge and benefitting from women's experience, due to their disposition, openness and greater empathy:

I_1: A different approach to a student, coming from the heart rather than from duties or the law; stronger commitment to work. Men are lazier. A fuller understanding and deepening of the relationship with my wife due to female colleagues confessing their problems concerning their partners.

I_18: Conscientiousness, reliability, responsibility; also sense of aesthetics - caring for the workplace.

I_13: Women are more refined and kind; they are more sensitive towards people. I don't see any tensions.

I_5: It gives an opportunity to work with people who are much more sensitive and have a different perspective on life.

I_3: Working with women helps me to look at certain issues from a different perspective - in a less analytical way. Sometimes emotions may help in relationships with other people.

The above opinions are suggestive of the fact that working with women may be an opportunity for men to discover and learn a different approach to life. Moreover, the statements clearly show a positive assessment of the female approach to work. Such a high rating may result from some weakness or uncertainty felt by men who work in educational and helping professions (to these days perceived in a stereotypical way as those in which women perform better). However, it is worth pointing out that the statements express men's humility and 
admiration for women. In the context of today's changes regarding the approach to how men perform in different social roles, the benefits indicated by the participants fit into the current image of a man - gentle and caring, striving for selffulfilment in various areas of life (Arcimowicz, 2008; Dudak, 2016).

One of the interviewees mentioned another advantage of working in a feminized environment; namely, no male competition. He expressed it in a quite original way:

I_7: There is no tiring 'manhood-measuring contest' (could women do it too, but in a different form?), which often takes place within male groups in the least appropriate moments.

An important benefit noted by the participants was the predominance of women in a work environment, which reduces the occurrence of conflicts:

I_6: In conflict or tense situations, men tend to be less impulsive.

I_4: Arguments in a female-dominated environment are less frequent.

Despite the generally positive assessment of working in a feminized environment, the narratives also included criticism connected with the issue of discrimination, being forced to back down in various situations, and being exposed to women's critical opinions:

I_16: More difficult tasks, greater responsibility, even wage and financial discrimination; frequent conflicts among women, gossiping, envy, mixing home with work.

I_18: Poor organization, predilection to being dominated.

I_11: A kind of disadvantage I can mention is the fact that it is difficult to break through with your own ideas in certain professional matters; more often than not you just give in.

I_5: Sometimes you are being thought less of by the society.

I_3: Jokes may sometimes be harsh, but they are not frequent enough to bother.

The statements above clearly reveal that the interviewees raised the issue of women's domination in the work environment with regard to decision-making. 
They also drew attention to the fact that if a man chooses to work in a profession that is considered to be a typically female job, he may be perceived as helpless and 'unmanly' (Fuszara, 2008).

The participants revealed another downside - the sense of necessity to share interests that are, according to the men, typically female:

I_7: I don't watch all these soap operas or romance films. I don't garden. Therefore, I have fewer topics to talk about.

I_15: Constant office gossip; conversations about television series that are not always intellectually demanding.

In assessments concerning the negative aspects of working in a femaledominated environment, the interviewees also indicated financial issues related to the fact that feminized professions are not extremely attractive in terms of earnings (Zachorowska-Mazurkiewicz, 2006):

\section{1: "Perhaps, if I worked somewhere else, I would earn more."}

One of the participants referred to the financial issues in a rather humorous way:

I_19: I don't see any major losses. But on second thought, I certainly do see them when I reach for my wallet on the $8^{\text {th }}$ of March. :)

A recurring theme regarding the downsides of working in a female-dominated environment was absence of male colleagues, and therefore no possibility to exchange views with other men. In their narratives, the interviewees clearly highlighted that they place great importance on 'male solidarity'. They value the possibility of receiving help and support from male colleagues, who understand the world in a different way than women. This is how they expressed it in their statements:

I_1: Also, a small number of male colleagues.

I_4: There are no 'guy things' to discuss; no man's perspective or male bonding.

The aim of the reported research was also to get to know respondents' opinions concerning general barriers that men encounter while deciding to choose 
a profession in a female-dominated environment. The narratives revealed the issues relating mainly to the environment being dominated by women:

I_19: Women constitute a majority and I think that it might scare men away.

An important point raised in the statements was the economic aspect:

I_1: It doesn't pay much. But it's not the fault of my female colleagues; men are more to blame.

I_7: Lower wages are generally common in feminized jobs.

Moreover, the interviewees placed great importance on the social opinions and stereotypes relating to men taking up discussed professions:

I_14: Men perform worse in some professions because they are less sensitive to other people's problems and suffering. Women are naturally more protective and better at listening.

I_18: Lack of acceptance from the family and friends; their claims that I would not be successful in a feminized profession.

I_12: Men working in female-dominated professions may be perceived as weaker, less resourceful, and effeminate.

I_3: I would mainly mention cultural barriers. I think it's influenced by the environment in which men function. Inner limitations are the main barrier.

However, it is worth emphasizing that in the narratives concerning the interviewees' own experiences, these aspects were not presented so clearly.

It is noteworthy that the participants observed current changes concerning social roles, namely moving away from gender stereotypes towards self-fulfilment and self-awareness in selected areas of life. This view can be illustrated by the following instances:

I_13: More and more often, barriers disappear. Nowadays we can find more men working in professions that were once assigned only to women and vice versa. The fear of being judged by the society and the closest people might create strong barriers; however, it seems to become less and less common. 
I_9: Most of all, mental barriers, if any.

I_5: I do not observe such barriers; maybe except from men's inner limitations.

The above statements clearly reveal a positive attitude to the changes that are currently taking place in regard to fulfilling professional roles. These days, more and more men find satisfaction in those areas of life that are stereotypically perceived as more attractive to women.

\section{Experiences of reactions from the environment - family and friends}

Undoubtedly, an important aspect determining the quality of human social functioning is the surrounding environment - family and friends, and their reactions to our life choices, including those related to career. The vast majority of the interviewees indicated a neutral or positive reaction to their choice of profession:

I_15: Reactions of my family and friends to my profession are neutral.

I_14: I haven't noticed any special reactions from my family.

I_19: Generally, I have not experienced any negative reactions, only the positive ones. A lot of women that I've met think that there are far too few men in this profession.

I_20: Having worked for so many years in the social welfare, I got to know most of the local community, and I have never experienced any negative reactions.

I_1: Nobody nags at me for doing a 'woman's job' or earning little. Fortunately, my wife also works at school.

I_5: My family and loved ones are proud of me. I have a lot of support from them.

I_3: My friends and family help me greatly. They often support me during hard times.

Among the statements, there were also those in which the participants indicated that the discussed professions are treated as the „lesser evil" than, for example, unemployment. One of the interviewees expressed it as follows: 
I_7: I think they're happy that I have a job; that I didn't have to go away to be a dishwasher or that I did not end up in jail.

This statement also revealed that working in a feminized profession is treated as a last resort, a necessity in the absence of other job offers or required competencies. Other participants put it in a similar way:

I_12: Generally, I don't get any reactions. If, however, some appear, they are like 'well, you have to work somewhere'. Only once did a friend smile when he heard that I work in a library. I think it rather had to do with the fact that this job is perceived as soft, with little going on.

I_6: There are no specific reactions from my family due to the current situation in the labour market.

Very few participants stated that they had experienced negative opinions from their relatives concerning their career choice:

I_18: "I often heard that my profession was unmanly; that I'd better change my job to one that is suitable for a man."

I_3: "Sometimes I hear jokes and comments about my job being 'not manly enough'."

One man emphasized that the family expressed compassion and concern:

I_17: They rather feel sorry for me and worry about my future.

The above statements show anxiety and doubts expressed by other people in regard to participants' jobs. This fact introduces slightly stereotypical perception of feminized professions, especially if they are taken up by someone from family or friends. Some narratives indicate that working in such professions is treated as temporary and having few opportunities for development.

\section{Conclusions}

The analysis of the conducted interviews showed a relatively positive image of men's experiences in feminized professions, which corresponds with the con- 
temporary trend to perceive the functioning of an individual and the social roles performed by them through the prism of diversity. These results are an important aspect of understanding the functioning of a person, whose decisions and experiences throughout life lead to self-realization and satisfaction from social roles taken up in accordance with their plans and expectations.

The narratives of the men about their experiences concerning working in a feminized environment showed high reflectiveness of the participants on the level of facts, meaning and sense. During the interviews, men reflected on the events that they recalled. Sometimes, it resulted in gaining a new perspective on specific situations they experienced.

The analysis of the material collected in this research allowed to formulate a set of research conclusions. Firstly, according to the majority of the interviewees, a work environment dominated by women does not determine the quality of work. Men do not see any particular difficulties resulting from gender stereotypes relating to their professions. For them, working among women is like any other job. Situations connected to being in the minority are regarded as positive. The few difficulties indicated by the respondents were more connected with the issue of assisting in activities requiring strength or technical knowledge, not with competencies related to a specific profession. Moreover, the interviewees treat their profession as an opportunity for self-development and for gaining experience which they would not be able to gain in a typically male environment. Interestingly, they treat these experiences as positive, too.

Among the difficulties and barriers occurring in feminized professions, the respondents mentioned mainly low wages and low prestige of the occupation. These experiences are in accordance with other research reports (Fuszara, 2008). Generally, the interviewees were aware of the limitations that men might face in a female-dominated environment. However, they indicated that they had not experienced such difficulties. An important aspect mentioned in the narratives was a noticeable absence of male colleagues. The analysis of the responses showed that in some professional situations, men experienced discrimination, especially in relation to distribution of tasks or decision-making. As assessed by the respondents, such an approach on the part of women seems to be caused by men being in the minority. Although the overall assessment of working in female-dominated professions was positive and the participants were satisfied with their jobs, they also mentioned financial issues. The studies conducted so far show that, despite low wages and low occupational prestige, men do get satisfaction from feminized jobs, especially when working in helping professions (Herudzińska, 2015). 
It is noteworthy that the narratives of the men do not indicate a society having negative opinions in regard of men working in "typically female" occupations. Participants' assessments regarding other people's reactions included statements expressing compassion and fear for the future rather than pure criticism. Most of the interviewees stated that they could count on the understanding and help of their family and friends.

The references and interpretations of situations experienced by the participants at work show to a large extent how important it is for people these days to be able to pursue a professional career in accordance with their own needs and interests. The results of the research concerning men's functioning in a femaledominated environment fit into the current image of a man - with opportunities to fulfil himself in various social roles corresponding to his own idea of fulfilment and success.

The reported research reflects the ongoing transformations in the area of occupational roles due to gender segregation and expands the existing knowledge on males' approach to changing their image in contemporary, continuously transforming society. The studies on contemporary men functioning in professional spaces reflect to a large extent Madeleine Arnot's claim that "[g]ender would no longer be ascribed and utilised as a principle of social organisation in the public sphere", and that there takes place a 'degendering' of "the world of politics, industry, culture and education. (Arnot, 2002, p. 153). This also concerns occupations, where segregating between typically male and female jobs is less and less common.

\section{References}

Arcimowicz, K. (2008). Przemiany męskości w kulturze współczesnej [Transformations of Manhood in Contemporary Culture]. In: M. Fuszara (Ed.), Nowi mężczyźni? Zmieniajace się modele męskości we wspótczesnej Polsce [New Males? The Changing Models of Manhood in Contemporary Poland] (pp. 21-60). Warszawa: Wydawnictwo TRIO.

Arnot, M. (2002). Reproducing Gender? Essays on Educational Theory and Feminist Politics. London: Routledge.

Blau, F., Ferber, M., \& Winkler, A. (2006). The Economics of Women, Men, and Work. Upper Saddle River, NJ: Pearson, Prentice Hall; England.

Blau, F.D., \& Kahn, L.M. (2000). Gender Differences in Pay. Journal of Economic Perspectives. American Economic Association, 14(4), 75-99, doi: 10.1257/jep.14.4.75.

Cross, S., \& Bagilhole, B. (2002). Girls' Jobs for the Boys? Men, Masculinity and Non-Tradi- 
tional Occupations. Gender, Work and Organization, 9(2), 204-226, doi: 10.1111/14680432.00156 .

Denzin, N.K., \& Lincoln, Y.S. (2009). Metody badań jakościowych [The SAGE Handbook of Qualitative Research]. Warszawa: Wydawnictwo Naukowe PWN.

Domagała, P., Kretowicz, K., \& Żuralska, R. (2013). Percepcja mężczyzn wykonujących zawód pielęgniarza w społeczeństwie [Social Perception of Males Performing in Nursing]. Problemy Pielegniarstwa, 21(4), 462-470.

Domański, H. (1999). Zadowolony niewolnik idzie do pracy [A Happy Serf Goes to Work]. Warszawa: Wydawnictwo Instytutu Filozofii i Socjologii PAN.

Dudak, A. (2016). Wizerunek współczesnego mężczyzny w roli ojca [An Image of the Contemporary Male as Father]. In: E. Ogrodzka-Mazur, G. Błahut, \& T.B. Chmiel (Eds.), Wspótczesne ojcostwo. Konteksty kulturowe, pedagogiczne i prawne [Contemporary Fatherhood. Cultural, Pedagogical and Legal Contexts] (pp. 13-23). Toruń: Wydawnictwo Adam Marszałek.

Dudak, A. (2019). Mężczyźni w zawodach sfeminizowanych - funkcjonujące stereotypy i ich konsekwencje w percepcji studentów [Males in Feminized Professions: Students' Perception of Active Stereotypes and their Consequences]. Annales UMCS, Sectio J, Paedagogia - Psychologia, 32(4), 217-230, doi: 10.17951/j.2019.32.4.217-230.

Dudak, A. (2019). Teachers' Perception of Men in the Feminised Occupations. Szkoła - Zawód-Praca, 17, 308-319, doi:10.34767/SZP.2019.01.20.

Dudak, A. (2020). Motywy wyboru przez mężczyzn zawodów sfeminizowanych [Motives for Male Choices of Feminized Professions]. In: S.M. Kwiatkowski, \& M. Piorunek (Eds.), Jednostka. Edukacja. Organizacja wobec przemian rynku pracy [An Individual. Education. Organization Versus Changes on the Labour Market] (pp. 29-38). Warszawa: Wydawnictwo Akademii Pedagogiki Specjalnej.

England, P. (2010). The Gender Revolution: Uneven and Stalled. Gender and Society, 24(2), 149-166, doi: 10.1177/0891243210361475.

Folga, A. (2016). Wizerunek bibliotekarza w opinii studentów I roku Uniwersytetu Pedagogicznego w Krakowie [An Image of Male Librarian in the Opinions of the $1^{\text {st }}$ Year Students at the Pedagogical University of Krakow]. Annales Universitatis Paedagogicae Cracoviensis FOLIA 210, Studia ad Bibliothecarum Scientiam Pertinentia, 14, 153-165, doi: 10.24917/20811861.14.10.

Fuszara, M. (Ed.) (2008). Nowi mężczyźni? Zmieniające się modele męskości we wspótczesnej Polsce [New Males? The Changing Models of Manhood in Contemporary Poland]. Warszawa: Wydawnictwo Trio. 
Gromkowska-Melosik, A. (2013). Feminizacja zawodu nauczycielskiego - „różowe kołnierzyki" i paradoksy rynku pracy [Feminization of the Teaching Profession: "Pink Collars" and Paradoxes of the Labour Market]. Studia Edukacyjne, 25, 75-90.

Herudzińska, M. (2015). Męskość na manowcach? (Nie)męski mężczyzna w opiniach mężczyzn [Manhood Gone Astray? (Un)manly Man in Male Opinions]. Dyskurs Młodych Andragogów, 16, 293-310.

Huffman, M. (2004). Gender Inequality Across Local Wage Hierarchies. Work and Occupations, 31, 323-345, doi: : 10.1177/0730888404266384.

Janicka, K. (1995). Kobiety i mężczyźni w strukturze społeczno-zawodowej: podobieństwa i różnice [Females and Males in Social and Professional Structures]. In: A. Titkow, \& H. Domański (Eds.), Co to znaczy być kobieta w Polsce [What Does it Mean to Be a Woman in Poland] (pp. 89-91). Warszawa: Wydawnictwo PAN.

Kamińska-Berezowska, S., \& Suchacka, M. (2015). Socjologiczne uwarunkowania problemów zadowolenia z pracy i rozwoju zawodowego bibliotekarzy [Sociological Conditioning of Job Satisfaction and Professional Development Among Librarians]. Bibliotheca Nostra. Ślaski Kwartalnik Naukowy, 4(42), 117-138.

Kapała, W., \& Rucki, P. (2008). Mężczyźni w polskim pielęgniarstwie. Jak widzą i oceniają swój zawód polscy pielęgniarze [Males in Nursing Profession in Poland: How they Perceive and Assess their Job]. Pielegniarstwo Polskie, 1(27), 7-13, doi: 10.20883/ issn.0860-8466.

Kaźmierczak, T. (2013). Mężczyźni - pracownicy socjalni, czyli o polskiej pracy socjalnej w perspektywie gender studies [Males - Social Workers: Polish Social Work in the Perspective of Gender Studies]. In: A. Kotlarska-Michalska (Ed.), Kobiety w pracy socjalnej [Females in Social Work] (pp. 501-514). Poznań: Wydawnictwo UAM.

Klimczak-Ziółek, J. (2005). Bibliotekarz jako zawód sfeminizowany - przyczyny i skutki [The Librarian as a Feminized Profession: Causes and Consequences]. In: Z. Dacko-Pikiewicz, \& M. Chmielowska (Eds.), Rola biblioteki narodowej w tworzeniu spoteczeństwa wiedzy [The Role of the National Library in Building Knowledge Society] (pp. 105-124). Dąbrowa Górnicza: Wydawnictwo WSB.

Kluczyńska, U. (2009). Mężczyźni jako grupa niejednorodna w dostępie do władzy i prestiżu [Males as a Heterogenous Group in Access to Power and Prestige]. In: K. Marzec-Holka, \& H. Guzy-Steinke (Eds.), Kapitat społeczny a nierówności - kumulacja i redystrybucja [Social Capital and Inequalities: Accumulation and Redistribution] (pp. 371-380), Bydgoszcz: Wydawnictwo UKW.

Kluczyńska, U. (2012). (Nie)obecność mężczyzn w pielęgniarstwie - funkcjonujące stereotypy i ich konsekwencje [(In)activity of Males in the Nursing Profession: Active Stereotypes and their Consequences]. Nowiny Lekarskie, 81, 5, 564-568. 
Kluczyńska, U. (2017). Mężczyźni w pielęgniarstwie. W stronę męskości opiekuńczej [Males in Nursing: Towards a Caring Manhood]. Poznań: Wydawnictwo Naukowe Uniwersytetu Medycznego im. K. Marcinkowskiego.

Kobiety i mężczyźni na rynku pracy [Males and Females on the Labour Market]. (2018). Retrieved 10 September 2020 from: file://C:/Users/user/Downloads/kobiety_i_mezczyzni_na_rynku_pracy_2018\%20(2).pdf.

Kuropatwa, A. (2014). Problem dyskryminacji kobiet - analiza wybranych teorii neoklasycznych opartych na założeniu o niekonkurencyjnych rynkach pracy [Female Discrimination: Selected Neo-classical Theories Based on the Assumption of Non-competitive Labour Markets]. Ekonomia - Wroclaw Economic Review, 20, 4, 53-68.

Lipińska-Grobelny, A., \& Goździk, I. (2012). Płeć psychologiczna a zadowolenie z pracy w zawodach stereotypowo męskich i kobiecych [Psychological Gender and Job Satisfaction in Stereotypically Male and Female Occupations]. Medycyna Pracy, 63, 5, 531-540.

Marcinkowski, P. (2005). Bibliotekarz. Stereotyp czy wizerunek? [The Librarian: A Stereotype or an Image?]. In: E. Bieniarz, K. Serwatko, \& B. Jaskowska (Eds.), Tradycja i nowoczesność bibliotek akademickich: materiały z ogólnopolskiej konferencji naukowej [Tradition and Contemporaneity of Academic Libraries: Proceedings of the National Research Conference] (pp. 93-106). Rzeszów-Czarna: Wydawnictwo Biblioteki Uniwersytetu Rzeszowskiego.

McDonald, J. (2013). Conforming to and Resisting Dominant Gender Norms: How Male and Female Nursing Students Do and Undo Gender. Gender, Work and Organization, 20(5), 561-579, doi:10.1111/j.1468-0432.2012.00604.x.

Moore, T.S. (2018). Occupational Career Change and Gender Wage Inequality. Work and Occupations, 45(1), 82-121, doi: 10.1177/0730888417742691.

Nowak, B.M. (2018). At Risk of Social Exclusion. Labor Market Disadvantage of Ex-Convicts - The Case of Poland. Przeglad Badań Edukacyjnych, 27(2), 85-96, doi: $10.12775 / 28158$.

Ostrouch, J. (2004). Nieuchwytne. Relacje matek i córek w codzienności [Intangible: About the Daily Relations of Mothers and Daughters]. Olsztyn: Wydawnictwo UWM.

Pokrzywa, M. (2016). Feminizacja zawodu pracownika socjalnego [Feminization of the Social Work Profession]. In: J. Husár, M. Machalová, T. Hangoni, \& B. Kuzyšin (Eds.), Nová sociálna edukácia človeka iv (duchovné, antropologické, filozofické, psychologické a sociálne aspekty terapie, výchovy, vzdelávania a poradenstva dneška) [The New Social Education of Man (Spiritual, Anthropological, Philosophical, Psychological and Social Aspects of Therapy, Education, Training and Counselling Today] (pp. 154-164). Prešov: Wydawnictwo Prešovská Univerzita v Prešove. 
Pokrzywa, M. (2017). Segregacja płciowa na rynku pracy na przykładzie zawodu pracownika socjalnego - przyczyny i konsekwencje [Gender Discrimination on the Labour Market: A Case Study of the Social Worker. Causes and Consequences]. Młoda Humanistyka.com, 3. Retrived 22 October 2020 from: http://www.humanistyka.com/index. $\mathrm{php} / \mathrm{MH} / \mathrm{article} / \mathrm{view} / 110 / 99$.

Reskin, B.F., \& Ross, P. (1999). Job Queues, Gender Queues: Explaining Women Inroads Into Male Occupations. Philadelphia: Temple University Press.

Shen-Miller, D., \& Smiler, A.P. (2015). Men in Female-Dominated Vocation: A Rationale for Academic Study and Introduction to the Special Issue. Sex Roles, 72, 269-276, doi: 10.1007/s11199-015-0471-3.

Shen-Miller, D., Smiler, A.P. (2015). Men in Female-Dominated Vocation: A Rationale for Academic Study and Introduction to the Special Issue. Sex Roles, 72, 269-276, doi: 10.1007/s11199-015-0471-3.

Simpson, R. (2009). Men in Caring Occupations: Doing Gender Differently. Basingstoke, UK: Palgrave Macmillan.

Urbaniak-Zając, D., \& Kos, E. (2013). Badania jakościowe w pedagogice [Qualitative Research in Education Studies]. Warszawa: Wydawnictwo Naukowe PWN.

Walczak, D. (2016). Prestiż zawodu nauczyciela w percepcji różnych aktorów życia szkoły [The Prestige of the Teaching Profession as Perceived by Various Stakeholders in School Life]. Studia z Teorii Wychowania, VII, 4(17), 93-115.

Whitaker, T. (2008). Who Wants to Be a Social Worker? Career Influences and Timing. NASW Membership Workforce Study. Washington DC: National Association of Social Workers.

Zachorowska-Mazurkiewicz, A. (2006). Kobiety i instytucje. Kobiety na rynku pracy w Stanach Zjednoczonych, Unii Europejskiej i w Polsce [Women and Organizations. Females in the US, EU and Poland's Labour Market]. Katowice: Wydawnictwo Śląsk.

Ziarkowski, D. (2019). Zaufaj mi, jestem bibliotekarzem, czyli mężczyzna w bibliotece [Trust Me, I Am a Librarian: Males in the Library]. Biblioteka i Edukacja, 16, 111-120. 